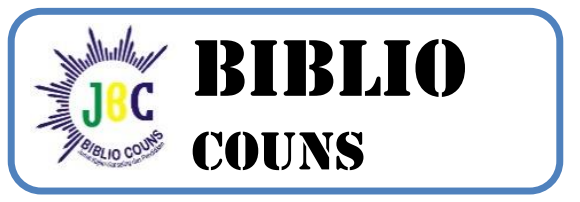

Biblio Couns : Jurnal Kajian Konseling dan Pendidikan

Vol. 2, No. 1, Maret 2019, hlm. 41-46

Tersedia Online di jurnal.umsu.ac.id/index.php/biblio

ISSN 2620-3103 (online)

\title{
GAMBARAN KEBIASAAN BELAJAR SISWA SERTA IMPLIKASINYA TERHADAP PELAYANAN BIMBINGAN DAN KONSELING
}

\section{Solihatun}

Program Studi Bimbingan dan Konseling, Unversitas Indraprasta PGRI, Indonesia, Korespondensi: JI. Nangka No. 58, (TB. Simatupang) Jakarta Selatan, DKI Jakarta.

\author{
Email: solihatun@unindra.ac.id
}

Article Info

History of Article

Submited September 2018

Accepted March 2019

Published March 2019

\section{Key Word \\ Study Habits, \\ Guidance and Counseling \\ Service}

\section{Kata Kunci}

Kebiasaan belajar,

Pelayanan Bimbingan

dan Konseling

\begin{abstract}
This study aims to describe the learning habits of students at Master Indonesia High School Depok. This study uses descriptive quantitative methods. The population of this study was 105 students, the sampling technique used a saturated sampling technique. The instrument used in this study is the Likert scale. The results showed that students' learning habits in the good category were equal to $54.29 \%$, good enough $36.19 \%$, very good category $5.71 \%$, poor category $3.81 \%$. The implications of the results of these studies can be used as an analysis of student needs for providing BK services in maintaining student learning habits.
\end{abstract}

\begin{abstract}
Abstrak
Penelitian ini bertujuan untuk mengetahui gambaran kebiasaan belajar siswa di SMA Master Indonesia Depok. Penelitian ini menggunakan metode deskriptif kuantitatif. Populasi penelitian ini sebanyak 105 orang siswa, Teknik pengambilan sampek menggunakan teknik sampling jenuh. Instrument yang digunakana dalam penelitian ini ialah skala likert. Hasil penelitian menunjukkan bahwa kebiasaan belajar siswa pada kategori baik yaitu sebesar yaitu sebesar $54,29 \%$, kategori cukup baik $36,19 \%$, kategori sangat baik $5,71 \%$, kategori kurang baik 3,81\%. Implikasi hasil penelitian tersebut dapat dijadikan sebagai analisis kebutuhan siswa untuk pemberian pelayanan BK dalam mempertahankan kebiasaan belajar siswa.
\end{abstract}

\section{Citation Info}

Solihatun. (2019). Gambaran Kebiasaan Belajar Siswa Serta Implikasinya Terhadap Pelayanan Bimbingan dan Konseling. In Biblio Couns: Jurnal Kajian Konseling dan Pendidikan, 2(01), 41-46. 


\section{PENDAHULUAN}

Sekolah merupakan lembaga pendidikan formal secara sistematis melaksanakan program bimbingan, pengajaran dan latihan dalam rangka membantu siswa supaya mampu mengembangkan potensinya, baik menyangkut aspek moralspiritual, intelektual, emosional dan juga aspek sosial" Yusuf, dkk (2010:60). Proses berkembangnya siswa tidak selalu berlangsung secara mulus, atau steril dari masalah. Dengan kata lain, proses berkembangnya individu atau siswa tidak selalu sejalan dalam alur linier, lurus, atau searah dengan potensi, harapan dan nilai-nilai yang dianut. Sehingga dalam belajar siswa harus memiliki beberapa hal permasalahan, salah satunya adalah keberhasilan belajar di kelas,

Anurrahman (2009:185) menjelaskan bahwa "Kebiasaan belajar merupakan perilaku belajar seseorang yang telah tertanam dalam waktu yang relatif lama sehingga memberikan ciri dalam aktivitas belajar yang dilakukannya". Artinya kebiasaan belajar yang baik dapat dilakukan secara berulang oleh siswa dengan cara latihan sehingga menjadi kebiasaan yang melekat pada diri siswa. Sedangkan menurut Prayitno (2008:265) menjelaskan kebiasaan belajar yaitu sesuatu yang biasa dikerjakan pada saat belajar secara teratur dan terarah untuk mencapai keberhasilan. Kebiasaan belajar bukanlah bakat alamiah atau bawaan (hereditas) akan tetapi merupakan perilaku yang dipelajari secara sengaja ataupun tanpa sadar dari waktuwaktu yang lalu, karena selalu diulang-ulang maka perilaku tersebut terbiasakan dan pada akhirnya terlaksana secara spontan.

Setiap siswa memiliki kebiasaan belajar yang berbeda-beda dalam mencapai prestasi belajar yang baik. Brown \& Holtzman (dalam Mendezabal, 2013:1) menjelaskan ada lima bentuk kebiasaan siswa dalam belajar, yaitu: (1) mengatur waktu, (2) menerima pelajaran, (3) membaca buku, (4) membuat catatan, dan (5) mengerjakan tugas.

Selanjutnya hasil penelitian Riska Andriani pada tahun 2017 menyebutkan bahwa gambaran kebiasaan belajar siswa SMA 1 padang terlihat bahwa secara ratarata kebiasaan belajar berada pada kategori baik, dengan tingkat capaian rata-rata sebesar $68,2 \%$. Hal ini juga terlihat dari analisis masing-masing indikator yang berada pada kategori baik. Namun, pada indikator mengatur waktu dan membaca buku masih berada pada kategori cukup baik yaitu $67,85 \%$ dan $57,27 \%$.

Berdasarkan keterangan dari guru SMA Master Indonesia Depok, kebiasaan siswa dalam mengikuti pelajaran masih kurang baik, seperti beberapa siswa masih datang terlambat, tugas dikerjakan di sekolah, terlambat dalam mengumpulkan tugas, duduk-duduk di kantin ketika jam pelajaran sudah dimulai, sering minta izin ke luar kelas. Kondisi demikian mengindikasikan bahwa kebiasaan belajar siswa di sekolah masih kurang baik. Permasalahan yang terjadi di SMA Master Indonesia Depok dapat ditangani oleh guru terutama guru BK.

Permasalahan diatas menunjukkan bahwa siswa yang memiliki kebiasaan belajar yang kurang baik Hal ini tentu saja tidak bisa dibiarkan begitu saja, sehingga penyelesaian masalah ini menjadi tanggung jawab semua guru, termasuk salah satunya adalah guru bimbingan dan konseling 
Bimbingan dan Konseling (BK) mempunyai peran penting dalam meningkatkan kebiasaan belajar siswa. Implikasi dari penelitian ini yaitu sebagai bahan masukan dalam program pelayanan BK di sekolah, khususnya layanan yang dapat diberikan dalam rangka membantu siswa memiliki kebiasaan belajar yang baik demi meningkatkan kebiasaan belajar di sekolah.

\section{METODOLOGI PENELITIAN}

Penelitian ini menggunakan metode kuantitatif jenis deskriptif. Menurut Lehmann (dalam Yusuf, 2013:61), "Penelitian deskriptif kuantitatif adalah salah satu jenis penelitian yang bertujuan mendeskripsikan secara sistematis, faktual, dan akurat mengenai fakta-fakta dan sifat populasi tertentu atau mencoba menggambarkan fenomena secara detail". Penelitian ini akan mendeskripsikan kebiasaan belajar siswa di SMA Master Indonesia Depok.

\section{HASIL PENELITIAN DAN PEMBAHASAN}

Berdasarkan hasil penyebaran angket kebiasaan belajar siswa terisolir di SMA Master Indonesia Depok, dikategorikan kedalam lima kategori yaitu; Tidak Baik, Kurang Baik, Cukup Baik, Baik, Sangat Baik. Menunjukkan bahwa sebagian besar siswa di SMA Master Indonesia Depok mengalami kebiasaan belajar yang Baik yaitu sebesar $54.29 \%$, sebagian siswa lainnya berada pada kategori sangat baik yaitu sebesar 5.71\%, dan siswa pada kategori cukup baik yaitu sebesar $36,19 \%$, selanjutnya memiliki kategori kurang baik 3,81\% dan tidak baik sebesar $0,00 \%$.

Tabel 1. Gambaran Kebiasaan Belajar siswa

\begin{tabular}{cccc}
\hline Interval Skor & Kategori & Frekuensi & $\%$ \\
\hline$\geq 134$ & Sangat Baik (SB) & 6 & 5.71 \\
\hline $108-133$ & Baik (B) & 57 & 54.29 \\
\hline $82-107$ & Cukup Baik (CB) & 38 & 36.19 \\
\hline $56-81$ & Kurang Baik (KB) & 4 & 3.81 \\
\hline 55 & Tidak Baik (TB) & 0 & 0.00 \\
\hline & Total & $\mathbf{1 0 5}$ & $\mathbf{1 0 0}$ \\
\hline
\end{tabular}

Selanjutnya, jika dilihat dari gambaran per indikator yang terdapat pada kebiasaan belajar diantaranya, adalah : memperlihatkan bahwa secara rata-rata dari keseluruhan indikator, kebiaasan belajar siswa berada pada kategori baik yaitu sebesar 70,12\%. Jika dilihat dari indikator kebiasaan belajar bahwa capaian terendah berada pada indikator membaca buku yaitu sebesar $62,75 \%$ dikategorikan cukup baik, berada pada kategori sedang mengatur waktu dan menerima pelajaran sebesar $70,77 \%$ dan $70,74 \%$, sedangkan dlihat dari indikator membuat catatan dan mengerjakan tugas pada kategori tinggi yaitu $76,25 \%$ dan $74,3 \%$. 
Biblio Couns : Jurnal Kajian Konseling dan Pendidikan | Vol. 2 No. 1 Maret 2019

\section{Tabel 2. Gambaran kebiasaan belajar jika dilihat per indikator}

\begin{tabular}{cccccccccc}
\hline No & $\begin{array}{c}\text { Sub } \\
\text { Variabel }\end{array}$ & \multicolumn{10}{c}{ Skeal } & Max & Min & $\sum_{\text {Sean }}$ & M & Sd & K \\
\hline $\mathbf{1}$ & $\begin{array}{c}\text { Mengatur } \\
\text { Waktu (7) }\end{array}$ & 35 & 35 & 11 & 2601 & 24.77 & 70,77 & 4.34 & B \\
\hline $\mathbf{2}$ & $\begin{array}{c}\text { Menerima } \\
\text { Pelajaran (7) }\end{array}$ & 35 & 32 & 16 & 2600 & 24.76 & 70,74 & 4.10 & B \\
\hline $\mathbf{3}$ & $\begin{array}{c}\text { Membaca } \\
\text { Buku (8) }\end{array}$ & 40 & 35 & 15 & 2637 & 25.1 & 62,75 & 3.90 & CB \\
\hline $\mathbf{4 .}$ & $\begin{array}{c}\text { Membuat } \\
\text { Catatan (4) }\end{array}$ & 20 & 20 & 5 & 1601 & 15.25 & 76,25 & 3.20 & B \\
\hline $\mathbf{5 .}$ & $\begin{array}{c}\text { Mengerjakan } \\
\text { Tugas (6) }\end{array}$ & $\mathbf{3 0}$ & 29 & 14 & 2342 & 22.30 & 74,3 & 3.17 & B \\
\hline Keseluruhan (32) & $\mathbf{1 6 0}$ & $\mathbf{1 4 2}$ & $\mathbf{8 4}$ & $\mathbf{1 1 7 8 1}$ & $\mathbf{1 1 2 , 2 0}$ & $\mathbf{7 0 , 1 2}$ & $\mathbf{1 4 . 0 1}$ & $\mathbf{B}$ \\
\hline
\end{tabular}

Hasil analisis data penelitian menunjukkan bahwa secara keseluruhan kebiasaan belajar siswa berada pada kategori baik. Namun demikian, masih terdapat variasi skor kebiasaan belajar siswa tersebut. Berdasarkan item yang ada pada indikator membaca buku item nomor 15, dan 21 berada pada kategori cukup baik. Keberhasilan dalam belajar tidak hanya ditentukan oleh kemampuan dasar saja, tetapi juga ditentukan oleh bagaimana cara belajar siswa itu. Cara yang dilakukan siswa dalam proses belajar sangat menentukan prestasi yang akan dicapai. Salah satu upaya untuk meningkatkan kebiasaan belajar yaitu disiplin terhadap waktu yang sudah direncanakan untuk belajar, hal ini merupakan langkah awal untuk mendapatkan hasil belajar yang maksimal.

Berdasarkan hasil temuan, maka perlu dilakukan upaya pelayanan BK untuk meningkatkan kebiasaan belajar siswa bervariasi. Penurunan prestasi siswa dapat terjadi dikarenakan kebiasaan belajar yang kurang baik. Hasil penelitian Lidgren (dalam Gie, 1995:194) menjelaskan bahwa kebiasaan belajar berperan penting dalam kesuksesan akademik, sehingga perlu dicarikan solusi untuk meningkatkan kebiasaan belajar siswa agar prestasi akademik siswa dapat meningkat.

Selanjutnya, penerapan layanan bimbingan kelompok dan layanan penguasaan konten merupakan alternatif layanan yang dapat diterapkan dalam meningkatkan kebiasaan belajar siswa yang bervariasi. Sesuai dengan manfaat dari layanan bimbingan kelompok adalah layanan yang membahas topi-topik umum yang menjadi kepedulian bersama anggota kelompok, Prayitno, (2012: 149) artinya melalui dinanika kelompok membantu individu agar dapat mencapai perkembangannya secara optimal sesuai dengan kemampuan, bakat, minat serta nilai-nilai yang dianutnya ditujukan untuk mencegah timbulnya masalah pada siswa dan mengembangkan potensi siswa.

Sedangkan Layanan penguasaan konten merupakan layanan bimbingan dan konseling yang membantu individu dalam menguasai konten tertentu, terutama kompetensi dan atau kebiasaan dalam melakukan, berbuat atau mengerjakan sesuatu yang berguna dalam kehidupan sekolah atau madrasah, keluarga, dan 
masyarakat sesuai dengan tuntutan kemajuan dan berkarakter cerdas yang terpuji, sesuai dengan potensi dan peminatan dirinya". Prayitno (2015:120)

Berdasarkan dekripsi data, hasil wawancara dengan Guru BK, dan analisis data dapat diketahui bahwa materi yang berkaitan dengan peningkatan atau pengembangan kebiasaan belajar siswa pelayanan BK bagi siswa Master Indonesia Depok yang tepat berkaitan dengan peningkatan kebiasaan belajar. Materi yang dapat diberikan seperti: konsep diri dalam belajar, cara belajar yang efektif, dan motivasi belajar. Semua itu terfokus pada empat bidang pengembangan BK di sekolah yakni bidang pengembangan pribadi, belajar, sosial, dan karier.

Selanjutnya, guru sebaiknya menciptakan suasana belajar yang kondusif secara berkelanjutan sehingga dapat membentuk kebiasaan belajar dan kecerdasan emosional siswa. Orang yang memiliki kebiasaan belajar baik, pada waktu yang direncanakan akan mendapat hasil belajar yang maksimal.

\section{KESIMPULAN}

Secara umum, Gambaran keterampilan sosial siswa terisolir di SMKN 20 Cilandak Jakarta Selatan berada pada kategori baik. yaitu sebesar 70,12\%. Jika dilihat dari indikator kebiasaan belajar bahwa capaian terendah berada pada indikator membaca buku yaitu sebesar $62,75 \%$ dikategorikan cukup baik, berada pada kategori sedang mengatur waktu dan menerima pelajaran sebesar 70,77\% dan $70,74 \%$, sedangkan dlihat dari indikator membuat catatan dan mengerjakan tugas pada kategori tinggi yaitu 76,25\% dan 74,3 \%. Adapun program pelayanan BK yang sesuai dengan kebutuhan siswa SMA Master Indonesia Depok dengan melihat rata-rata cukup baik yaitu terletak di indikator membaca buku yaitu sebesat $62,75 \%$, maka, Penerapan layanan bimbingan kelompok dan layanan penguasaan konten merupakan alternatif layanan yang dapat diterapkan dalam meningkatkan kebiasaan belajar siswa.

\section{REFERENSI}

Andriani, R. 2017. "Hubungan kebiasaan belajar dan dukungan sosial orang tua dengan prestasi belajar siswa SMA Pertiwi 1 Padang serta Implikasinya dalam Program Pelayanan Bimbingan dan Konseling. Tesis tidak diterbitkan. Padang: Program Studi S2 Bimbingan dan Konseling Fakultas IImu Pendidikan Universitas Negeri Padang.

Anurrahman. 2009. Belajar dan Pembelajaran. Bandung: Alfabeta.

Gie, T. L. 1995. Cara Belajar yang Efisien. Yogyakarta: Liberty.

Mendezabal, M. J. N. 2013. "Study Habits and Attitudes: The road to academic success". Open Science Repository Education, (Online). (http://www.openscience-repository.com/study-habits-and-attitudes-the-road-to-academicsuccess.html, diakses Maret 2016).

Prayitno. 2008. Dasar Teori dan Praksis Pendidikan. Padang: UNP Press. 
Prayitno. 2012. Jenis Layanan dan Kegiatan Pendukung Konseling. Padang: UNP Press.

Prayitno. dkk. 2015. Pembelajaran Melalui Pelayanan BK di Satuan Pendidikan. Paramitra Publsihing.

Yusuf, A. M. 2013. Metodologi Penelitian Kuantitatif, Kualitatif, dan Penelitian Gabungan. Padang: UNP Press.

Yusuf, S, Saripah, Ipah, \& Agustin, Mubiar. (2010). Bimbingan Etika Pergaulan Bagi Pengembangan Karakter Remaja. Bandung: Rizqi press. 